\title{
Moral Enhancement and the Human Condition.
}

\section{Edward Skidelsky}

'Moral enhancement' refers to the project (still purely notional) of enhancing the moral capacities of humanity through drugs, genomic editing and other such technologies. Its supporters present it as expedient, necessary even, to avert the potentially catastrophic misuse of nuclear and biological weaponry and to revive our slackening enthusiasm for the fight against global warming. Technology, they say, has brought us to the brink of disaster; so now we need a new technology, a technology of the self, to reel us back again. ${ }^{1}$

Critics of moral enhancement have generally focussed on its consequences for the enhanced, arguing that they would be robbed of autonomy or placed on an unequal footing vis-a-vis the non-enhanced. My own critique of the enhancement project is different, though not necessarily contradictory, to this. Its focus is not men but Man, not individual humans but the human 'form of life'. This form of life is (I suggest) the foundation on which all judgements of human goodness and badness ultimately rest; hence its dissolution through enhancement technologies would rob such judgements of their point and purpose. Moral enhancement is thus revealed as a self-defeating project: its fulfilment would mean the disappearance of the very conditions that could permit us to describe it as an 'enhancement'. We risk finding ourselves in a situation in which humanity has been not so much enhanced as replaced by an altogether different form of life, with different standards of excellence and deficiency.

\section{Meta-ethical assumptions}

The following reflections are based on meta-ethical assumptions which are broadly Aristotelian and naturalistic. I will not argue for those assumptions directly, but the chapter as a whole can be seen as a kind of abductive demonstration of them: insofar as the prospect of a 'morally enhanced' humanity repels us, and insofar as Aristotelian naturalism explains and justifies that repulsion better than rival theories, we have reason to be Aristotelian naturalists.

\footnotetext{
${ }^{1}$ This, in very brief outline, is the argument of 'The Perils of Cognitive Enhancement and the Urgent Imperative to Enhance the Moral Character of Humanity', the article in which Ingmar Persson and Julian Savulescu first launched the concept of moral enhancement. See Ingmar Persson and Julian Savulescu, 'The Perils of Cognitive Enhancement and the Urgent Imperative to Enhance the Moral Character of Humanity', Journal of Applied Philosophy 25/3 (August 2008), 162-177.
} 
So readers with a prior commitment to Aristotle can find in here an argument against moral enhancement, and readers with a prior aversion to moral enhancement can find in here a vindication of Aristotle. And readers with no brief for Aristotle and no aversion to moral enhancement can give up now: this chapter is not for you.

Aristotelian naturalism is the view, roughly speaking, that judgements of goodness and badness are not absolute but relative to particular forms of life. When I point at a thing and describe it as 'good' I tell you next to nothing about it until you know what form of life it embodies, or what role it might play in a form of life. Everything that is good or bad is good or bad 'as' or 'for' one or another form of life. There is no goodness or badness on barren Mars, except insofar as we think of it as the potential environment of some living thing. ${ }^{2}$

What is true of goodness and badness in general is true also of the various species of goodness and badness. Strength, swiftness, intelligence and health are all relative to one or another form of life: a swift bear would make a very slow cheetah, and a clever lion would make a rather stupid chimp. Moral goodness, though unique to us (we being the only creatures capable of acting on reasons), is no different in principle: it too is a requirement of a particular form of life, dependent on that form of life for its specific shape and colour. Were human life to be radically other than what it is, human morality would be too. Philippa Foot gives the example of trustworthiness:

It is easy to see how much good hangs on trustworthiness if one thinks, for instance, of the long dependency of the human young and what it means to parents to be able to rely on a promise securing the future of their children in the case of their death. It would be different if human beings were different, and could bind the wills of others through some kind of futurerelated mind-control devise. But we have not got such powers, any more than animals who depend on cooperative hunting have the power to catch their prey as tigers do, by solitary stalk and pounce. ${ }^{3}$

These remarks can easily be construed in a utilitarian sense, as implying that trustworthiness is good only as a means to some independently desirable end. That is not what Foot means,

\footnotetext{
${ }^{2}$ See Philippa Foot, Natural Goodness (Oxford: Clarendon Press, 2001), 27. I have borrowed this example from her.

${ }^{3}$ Foot, Natural Goodness, 45.
} 
however. She regards trustworthiness as good in itself, but only because of its role in the economy of human life. This is not the paradox it might at first seem. All goods require a setting, a place in an accustomed form of life. The value of an icon, though not in any sense instrumental, is nonetheless dependent that icon's role in the liturgical life of the church. Detach it from that role, put it behind glass in a museum, and it becomes just a pretty piece of painted wood. The moral virtues are no different in principle. They too depend for their value on their role in the human form of life.

Utilitarians and Kantians both reject any notion of specifically human goodness. For utilitarians, goodness is wellbeing, which is fundamentally the same for all sentient beings, though some of its dimensions may be available to some and not others. For Kantians, goodness is goodness of the will, which is identical in all rational agents. But as I said, I'm not going to argue the case against utilitarianism and Kantianism here. I'll just note the disagreement and move on.

I use the expression 'form of life' rather than the scientific 'species' in recognition of the unique malleability of human existence, which means that biology cannot by itself determine our standards of weal and woe. It must be supplemented by those perennial features of our lived environment which together with our biology make up what Hannah Arendt called 'the human condition' or what I am calling the human 'form of life' ${ }^{4}$ Consider again the quotation from Philippa Foot. If humans ever did succeed in creating some 'future-directed mind-control device' then trustworthiness as we understand it would no longer be a virtue. This means that the lack of such a device, though not implicit in our species nature, must nonetheless be considered as part of our 'form of life'.

Which other features of our lived environment should be included in our form of life? Aristotelians will presumably not want to cast the net too wide, or they risk endorsing a cultural relativism they usually reject. But I think the following would be on most people's lists:

- The fact that our innate constitution is the product of chance, not design.

- The fact that we live on the surface of the earth, not scattered across the galaxy.

- The fact that we cannot expect to live much past three score years and ten.

\footnotetext{
${ }^{4}$ See Hannah Arendt, The Human Condition (Chicago: The University of Chicago Press, 1958), 1-6.
} 
These three features of our condition could all be abolished without transforming us into a different species in the biological sense, but their abolition would, I take it, transform us into a radically different 'form of life', with different possibilities of flourishing and foundering. (Just imagine the qualities of character required to endure 300 years of conscious existence, or to find fulfilment on alien planets.) It is no accident that post-humanists have pressed for the abolition of these three limitations in particular, for they seem more than others to define our 'creaturely' condition, our dependence on circumstances not of our making.

\section{Strong, stronger, strongest}

Before turning to our chief subject of moral enhancement, it will be useful to linger for a moment on a purely physical enhancement. The argument in both cases is similar in structure.

Strength, like other excellences, is relative to particular forms of life. A strong man suffers nothing by comparison with a gorilla, for his is a specifically human strength, perfectly adequate to the tasks that humans are called on to perform: cycling to work, carrying children and furniture, and so forth. Of course, there is a good deal of cultural and historical variety here. Some ways of life demand more in the way of physical strength than others. But this is a variety within limits. No human society calls on its members to pluck trees out by their roots or to kill buffalo barehanded. These are not 'normal' human activities.

Now let us suppose that an advance in genetics, or pharmaceuticals, or some combination of the two - it doesn't matter for present purposes - allows human beings to become progressively stronger, year after year. To be clear, I am not imagining a situation in which all humans are brought asymptotically up to a limit of strength, but one in which this limit is itself progressively extended. Over the decades, humans metamorphose into creatures resembling the Incredible Hulk, or even more fantastic monsters.

In such a world, we could no longer describe an individual as 'strong', at least not in the familiar sense, for the background conditions that give determinate content to such a statement would have disappeared. At best, we might say things like 'he's strong for someone born in 2020, but of course, things have come on a long way since then' or 'she's strong for someone from India, but the technology over there is still quite rudimentary.' In short, the content of 'strong' would be indexed not to a form of life but to contingent features of a given 
individual's historical and social situation. Everyone would be becoming progressively stronger, yet no one could be described as simply strong.

It is worth pondering for a moment the likely psychological effects of this transformation. In our world, people generally want to be stronger, or at least not weaker, so as to be able to discharge the normal human functions. But this could not be their motive in the world I have described, for in this world there would be no such thing as 'the normal human functions' but only a range of functions expanding progressively in tandem with our strength. In this world, the only possible motive for wanting to be stronger would be to become stronger than other people, or at least not weaker than other people. In other words, opening up the limits of human strength would have the effect of making the desire for strength a competitive one, rather like the desire for money. ${ }^{5}$ We can see the beginnings of this dynamic already. Bodybuilders, using advanced machinery and (often) powerful drugs, are able to develop their muscles far beyond the limits of what is required in the normal course of life. Their motive for engaging in this strange behaviour is purely competitive: they want to keep up with, or stay ahead of, other bodybuilders. An enhanced future would see us all in this unhappy situation.

\section{Moral Enhancement}

Let us turn to the question of moral enhancement. 'Moral enhancement' will of course mean different things to people with different moral views. The originators of the concept, Julian Savulescu and Ingmar Persson, are sensibly unspecific on the matter. They identify the core moral dispositions as altruism, defined as 'the sacrifice of one's own interests for the welfare of others', and justice, identified with what game theorists call a 'tit-for-tat' strategy. ${ }^{6}$ This may seem rather simplistic, but let that pass. My argument against moral enhancement is consistent with any view of the content of morality.

Moral enhancement refers, then, to the strengthening of our moral dispositions (whatever these might be) through drugs, surgery and other biomedical procedures. Alleged examples include the use of serotonin reuptake inhibitors like Prozac 'to make subjects more fair-

\footnotetext{
${ }^{5}$ Mainstream economics assumes that people want money simply in order to acquire the goods that they want, regardless of what others have. But this ignores the way in which consumer wants are themselves shaped by social expectations. See Robert H. Frank, Luxury Fever: Weighing the Cost of Excess (Princeton: Princeton University Press, 2010).

${ }^{6}$ See Julian Savulescu and Ingmar Persson, 'Moral Enhancement, Freedom, and the God Machine', The Monist 95/3 (July, 2012), 407-8.
} 
minded and willing to cooperate' and the use of deep-brain stimulation to modify addictive behaviours. ${ }^{7}$ The implied moral psychology is Humean: moral conduct is not the product of some 'will' distinct from our natural inclinations but of those inclinations themselves. To have a moral disposition is simply to want to do the right thing, in the same sense that we want to eat or make love. Again, there may be plenty to object to here, but let that pass; my target is elsewhere.

Savulescu and Persson appear, then, to be committed to the following two theses, though they don't state them explicitly:

Thesis 1: A morally ideal agent is one who is inclined to act only morally, never immorally.

Thesis 2: A morally ideal world is one in which all agents are morally ideal, in the sense given above.

Thesis 1 is a straightforward consequence of Savulescu and Persson's moral psychology. And Thesis 2 seems to follow from Thesis 1 together with some simple and plausible assumptions about aggregation: if it is better for any particular agent to be morally ideal, it must be best for all agents to be morally ideal.

Critics of Savulescu and Persson have tended to focus on Thesis 1. John Harris, in particular, has argued that moral enhancement, by making it impossible for us to act immorally, would destroy the 'freedom to fall' that is, for Harris, a condition of genuine moral worth. ${ }^{8}$ Savulescu and Persson are (rightly in my view) unpersuaded by this objection. They point out that the morally enhanced would be 'unfree' to act badly only in the familiar, uncontroversial sense of being motivationally incapable of it. ${ }^{9}$ Aristotle's crown of virtue is also 'unfree' to do the bad thing, meaning simply that it is psychologically out of the question for him; and while one might doubt the empirical plausibility of such a figure, it is hard to deny that he represents an ideal. At any rate, it is bizarre to suppose that perfect virtue requires a continual struggle against our baser impulses.

A modified version of Harris' objection might run as follows: even if the morally ideal agent feels no inclination to act immorally now, he must have a) felt some such inclination at some

\footnotetext{
${ }^{7}$ Savulescu and Persson 'Moral Enhancement, Freedom, and the God Machine', 400-405.

8 John Harris, 'Moral Enhancement and Freedom', Bioethics 25 (2011), 102-111.

${ }^{9}$ Savulescu and Persson, 'Moral Enhancement, Freedom, and the God Machine', 409.
} 
point in his past and b) overcome it through his own efforts. In other words, his good character must be a product of his own volition, not a gift of fortune or technology. I'm not so sure. The roots of character are deeply buried in early longings and traumas, which age can moderate to a degree but never entirely overcome. 'At 50, everyone has the face he deserves' wrote Orwell, memorably but falsely. Does anyone have the character he deserves, at 50 or at any other age? And if not, can we withhold the highest praise from someone whose character is blatantly undeserved? Apart from anything else, this would rule out those saints who swore that they were nothing except through God's grace.

I don't have answers to these questions myself. But I'll leave the point moot, since my target is not Thesis 1 but Thesis 2. Even if we concede, for the sake of argument, that an agent who feels no inclination and has never felt an inclination to act immorally might be morally ideal, it does not follow that a world of such agents would be morally ideal. Why not?

I have said that our virtues depend on our form of life; were this form of life different, those virtues would also be different. One aspect of this dependency was highlighted by Aristotle when he said the virtues are about what is difficult for men. ${ }^{10}$ Maternal love is not usually regarded as a virtue, though it is certainly necessary for the flourishing of human life, because with rare exceptions it comes easily and spontaneously. By contrast, filial piety can and has been reckoned a virtue precisely because it does not come easily or spontaneously; it requires deliberate cultivation. The virtues, explains Philippa Foot, 'are corrective, each one standing at a point at which there is some temptation to be resisted or deficiency of motivation to be made good. ${ }^{11}$ This statement can be misunderstood as implying that only those who feel the tug of vice can be called virtuous - a view often (though probably falsely) attributed to Kant. That is not what Foot means, though. The perfectly just person feels no temptation at all to do the unjust thing, but it remains the case that justice is a virtue only because human beings in general are often tempted to be unjust. If we felt no inclination to be unjust, there would be no need for a virtue of justice, any more than there is need for a virtue of maternal love. Such a virtue would have no functional role in our lives.

With this in mind, let us return to Thesis 2. It states that a morally ideal world is one in which all agents are morally ideal, in the sense that they feel no inclination at all to act immorally. In such a world, the motives of justice, benevolence etc. would require no cultivation; they

\footnotetext{
${ }^{10}$ Nicomachean Ethics II.9.

${ }^{11}$ Philippa Foot, Virtues and Vices (University of California Press, 1978), 8.
} 
would operate as strongly and spontaneously as does the motive of self-preservation in our actual world. We would all love our neighbours as we love ourselves, without any effort or struggle. This is (I take it) Savulescu and Persson's ideal. But my question now is this: in what sense is this a morally enhanced world as opposed to one in which morality, as we understand it, has no place or purpose? For it seems that once the shortcomings and defects that our moral virtues serve to correct have been eradicated those virtues themselves must fall away as superfluous. There will then be no need for justice or benevolence, any more than there is now for a virtue of maternal love. Other virtues might still be relevant, of course. Morally enhanced humans would presumably still have use for notions such as 'clever', 'competent', 'inquisitive', and so forth. But the specifically moral virtues would have no foothold in their lives.

Three responses might be made on behalf of the moral enhancers. First, it will be said that Thesis 2 follows mathematically from Thesis 1, whose truth I have already conceded. It doesn't, however. This is a version of the 'fallacy of composition', familiar to economists. I can view the match better standing up, but it doesn't follow that everyone can view the match better standing up. I am wise to save, but it doesn't follow that everyone would be wise to save. Linguistics offers an even closer analogy. If some people use 'who' to mean 'whom', they are breaking the rules of English; if all people use 'who' to mean 'whom', the rules of English have changed. Grammatical error cannot be universalised. Neither can moral perfection.

Second, it might seem that traditional moral education, insofar as it too aims at universal perfection, is pregnant with the same contradiction I have discerned in moral enhancement. But this is a misconception. Plato and Christ never aspired to make sages or saints of more than a small minority. Material conditions, as well as the inherent mediocrity of our kind, did not permit them to hope for more. Even in our democratic age, no one really supposes that education alone can change the frame of human nature. Moral enhancement, by contrast, is an avowedly universalist project, whose goal is the transformation of humanity as such. This goal is implicit in the project's original rationale as expounded by Savulescu and Persson: to protect the world from our collective greed, or from the threat posed by a single rogue agent. Enhancement has to be universal, or it will not save us.

Finally, it will be retorted that my argument, even if sound, is ludicrously beside the point. The abolition of morality is a small price to pay for averting global catastrophe. One might 
point out that someone who argues like this is not really concerned with moral enhancement at all but with the avoidance of certain undesirable states of affairs, but that would be quibbling. The substantive point at issue is this: is the eradication of the suffering flowing from our evil natures worth the abolition of morality? A question this big can only be answered personally. It seems to me (to paraphrase something Dr. Johnson said about marriage) that although our current world is full of evil, a morally enhanced world would be devoid of good. The entire interest of human life lies in the struggle between good and evil; abolish that struggle, and human life would be transformed into something utterly flat and without incident, like the life of ants or bees. 'What excites and interests the looker-on at life,' wrote William James, 'what the romances and the statues celebrate and the grim civic monuments remind us of, is the everlasting battle of the powers of light with those of darkness; with heroism, reduced to its bare chance, yet ever and anon snatching victory from the jaws of death. ${ }^{12}$ But of course, one can't expect a utilitarian to agree with me and James about this.

\section{The Invasion}

It is hard to imagine a transformation of the human form of life of the kind envisaged here. This is where film can help out. The Invasion (Oliver Hirschbiegel, 2007) is a remake of the old sci-fi classic, The Invasion of the Body-Snatchers. Although not entirely successful as a movie, it has the merit, from my point of view, of bringing out the philosophical issue that interests me clearly, somewhat obtrusively even.

The film depicts the colonisation of human life by an alien virus, borne to earth on the debris of a crashed space shuttle. The virus' effect on its hosts is immediate and dramatic. Physical appearance, memory and intellect are left intact, but all personal emotion is extinguished and replaced with one overriding drive: to spread the virus as widely as possible. Infected individuals are recognisable by their calm, impassive tone of voice and by the uncanny synchrony of their movements, as if they were radio-controlled by some central intelligence. They can put on a show of human feeling when talking to the uninfected, but left to

\footnotetext{
${ }^{12}$ William James, 'What Makes a Life Significant?', in John McDermott (ed.), The Writings of William James (Chicago: University of Chicago Press, 1977), 647.
} 
themselves they are usually silent, presumably because they understand each other perfectly without words. In sum, they are moral zombies. ${ }^{13}$

These creatures are not just out to spook us, however. They have (or claim to have) a high moral mission: to replace the bloody conflicts of human life with perpetual peace and harmony. The movie comes to a climax with the following dialogue between the recently infected Ben (Daniel Craig) and his still uninfected girlfriend, Carole (Nicole Kidman):

Ben: You were wrong to fight them. Do you remember our trip up to Colorado? Do you remember the aspen grove? How beautiful and peaceful it was? You remember what you said to me?

Carole: I didn't say anything to you.

Ben: $\quad$ You wondered what it would be like if people could live more like those trees, completely connected with each other, in harmony, as one.

Carole: You're not Ben. I know you're not Ben!

Ben: I'm not just Ben. I'm more than Ben. [Opens door to let others in.]

Carole: [Waving gun] Stop! Don't open that door!

Ben: Have you seen the television? Have you read the newspapers? Have you seen what's happening here and what we're offering? A world without war, without poverty, without murder, without rape. A world without suffering. Because in our world, no one can hurt each other or exploit each other or try to destroy each other. Because in our world, there is no other. You know it's right, Carole. Deep down inside, you know that fighting us is fighting for all the wrong things. Carole, you know it's true. Our world is a better world. ${ }^{14}$

Can we describe these alien beings as 'morally enhanced'? They certainly seem to possess many of the standard virtues. They are selfless and impartial. They are unhesitatingly self-

\footnotetext{
${ }^{13}$ A 'moral zombie' possesses consciousness and reason but lacks personality. I owe this useful concept to philosopher Rodion Garshin (private conversation).

${ }^{14}$ The Invasion (Oliver Hirschbiegel, 2007).
} 
sacrificing: they will walk into gunfire or in front of moving cars at the drop of a hat. In fact, they seem to have no personal attachments whatever, even to their own lives. In this sense, they are rather like Stoic sages. On the other hand, their complete lack of love or joy makes it hard for us to think of them as morally ideal, since (for most of us) morality has to do with affections as well as actions. So perhaps we can sharpen our dilemma by imagining these alien creatures as capable of certain affections. Of course, these would have to be affections consistent with their strict impersonality, so romantic or familial bliss is out of the question. Christian agape and 'joy in the Lord' might come closer.

Taken individually, such creatures might be described as morally ideal. However, their world, so far from being morally ideal, is one in which morality as we conceive it has no place at all. Saintly behaviour is admirable in humans precisely because it is rare and (for most of us) difficult. Make it universal and instinctive, and it becomes a matter of mere zoological interest, like lactation. The alien world is depressingly devoid of moral drama. We feel that nothing of deep significance could ever happen in this world, though it might be full of enjoyable experiences and technical discoveries.

Take the particular case of courage. In a scene towards the end of the film, the aliens are shown clinging threateningly onto Carole's moving car as she tries to shake them off. The image evoked - deliberately, I think - is one of swarming bees. In human beings, such behaviour might be called courageous, but one hesitates to call these creatures courageous. On the contrary, there is something disgusting about the sight of humans (as they appear) throwing away their lives like insects. It's not that we expect courageous people always to manifest signs of inner struggle. Perhaps, as Aristotle claims, the perfectly courageous man feels no fear at all except where fear is due. Nonetheless, what makes his action courageous is that fact that most people in his situation would feel fear. Here, as elsewhere, the individual act receives its significance from its place in a form of life.

\section{Conclusion}

I suggested near the beginning of this chapter that my argument as a whole could be considered as a kind of abductive demonstration of Aristotelian naturalism. I hope it is now clear what I meant by that. Most of us would, like Carole, reject Ben's offer of a 'better world'. That world instinctively revolts us, and would continue to do so even if we imagined away its more overtly B-movie features - the cold, staring eyes, the mechanical gestures, etc. 
Reflection on this revulsion reveals its intellectual basis: the alien world offers no foothold for judgements of moral excellence and deficiency, for those judgements are grounded in our specifically human form of life. In other words, our response to Ben's offer shows us to be Aristotelian naturalists, conscious or otherwise.

Of course, not everyone will be revolted by Ben's offer, just as not everyone is revolted by the analogous prospect of moral enhancement. To such people, I have offered an argument, based on the assumption that Aristotelian naturalism is indeed a correct account of moral judgement. But those who are neither revolted by moral enhancement nor convinced of the truth of Aristotelian naturalism will find nothing here to ruffle their certainties. Such is the nature of philosophical argument. 